Research Article

\title{
In Vitro Bioactivity of Binary Nepheline-Fluorapatite Glass/Polymethyl-Methacrylate Composite
}

\author{
Dalia Y. Zaki $\mathbb{D}^{1}$ and Esmat M. A. Hamzawy $\mathbb{D}^{2}$ \\ ${ }^{1}$ Restorative and Dental Materials Department, National Research Center, Cairo, Dokki 12622, Egypt \\ ${ }^{2}$ Glass Research Department, National Research Center, Cairo, Dokki 12622, Egypt \\ Correspondence should be addressed to Esmat M. A. Hamzawy; ehamzawy9@gmail.com
}

Received 1 January 2018; Revised 15 March 2018; Accepted 8 May 2018; Published 24 June 2018

Academic Editor: Michele Iafisco

Copyright ( 2018 Dalia Y. Zaki and Esmat M. A. Hamzawy. This is an open access article distributed under the Creative Commons Attribution License, which permits unrestricted use, distribution, and reproduction in any medium, provided the original work is properly cited.

\begin{abstract}
In vitro bioactivity of stoichiometric nepheline-fluorapatite glass/polymethyl-methacrylate $\left(\mathrm{PMMA}\left(\mathrm{C}_{5} \mathrm{O}_{2} \mathrm{H}_{8}\right)_{n}\right)$ composite was evaluated. Four glasses of nepheline/fluorapatite with different ratios (75/25, 80/20, 85/15, and 90/10 mole\%) were added in 20 and 40 wt.\% to PMMA. The composite samples were soaked in simulated body fluid (SBF) for 25 days. A scanning electron microscope with energy dispersive X-ray microanalysis (SEM/EDX) and thin film X-ray diffraction analysis was used to evaluate the composite materials after immersion in SBF. Inductively coupled plasma (ICP) and pH changes were used in the determination of the ions released and the alkalinity, respectively, after the immersion in Tris-buffered solution. Effect of glass filler loading on compressive strength of the cements was also evaluated. The four binary nepheline-fluorapatite glasses/PMMA cements composites are good potential bioactive materials. The compressive strength was between $70.36 \pm 6.47$ and $97.30 \pm 3.90 \mathrm{MPa}$. In general, decreases of the compressive strength follow the increase of the glass ratio (i.e., $40 \mathrm{wt}$ \%), but all meet that specified by the ASTM F-451.
\end{abstract}

\section{Introduction}

Some compositions of glasses, namely, bioactive glass composed mainly of silica, sodium oxide, calcium oxide, and phosphates, proved to have the ability to bond chemically with bone when implanted into living tissues. Such bonding is a result of a series of reactions in the glass and its surface. An exchange of monovalent cations from the glass, with $\mathrm{H}_{3} \mathrm{O}^{+}$from surrounding body fluid, takes place resulting in an increase in the $\mathrm{pH}$ of the surrounding fluids. A slight alkaline medium is a favorable medium for osteoblasts responsible for bone formation. Such increase in $\mathrm{pH}$ should be within a limit to prevent the inhibition of osteoblast activity and to prevent cell necrosis or apoptosis [1,2].

Bioactive glass has the ability to develop an adherent interface with tissues through the formation of a biologically active hydroxyl carbonate apatite (HCA) layer that resists significant mechanical forces. The strength of the developed adherent interface may be equivalent or greater than the cohesive strength of the implant material in some cases. The rapid reaction at the surface is important to provide a fast bonding with the tissues [1].

Several bioactive glasses, ceramics, glass ceramics, and composites with different compositions were discovered. Their behavior toward tissues was found to be dependent on their composition. Slight changes in the composition were found to greatly affect the properties and hence their application. Bioactive glasses have been used as a reconstruction material in treatment of the bone, and certain compositions have the ability to bond to soft tissues. The controlled rate of degradation and bonding to the tissue could be made through providing a special composition of the prepared glass [3].

The hydrolysis time of glass is a significant property when intended for use in the human body as an implant material. Phosphate glasses with high solubility rates are commonly used as suture thread and as drug delivery carriers. For glass-based materials designed for long-term application in the human body, decreasing solubility as much as possible without losing the bioactive property is essential [4]. Previous studies indicated that the addition of 
$\mathrm{Al}_{2} \mathrm{O}_{3}$ decreased the solubility of phosphate glass to an acceptable limit, thus increasing the long-term stability of the glass materials which is essential for bone defect repairing $[4,5]$. Decreasing solubility through the addition of $\mathrm{Al}_{2} \mathrm{O}_{3}$ allows the HCA layer to live for longer time on the glass surface. A study done by Mikhailenko et al. [6] revealed that aluminum oxide increases the glass stability in water media, while silicon oxide strongly decreases the resistance of glasses rendering them hydrolytically unstable.

In a recent study done by Hamzawy et al. [7], in $\mathrm{Na}_{2} \mathrm{O}-\mathrm{CaO}-\mathrm{Al}_{2} \mathrm{O}_{3}-\mathrm{SiO}_{2}-\mathrm{P}_{2} \mathrm{O}_{5}-\mathrm{F}$ system, the stoichiometric binary nepheline-fluorapatite phases were prepared and investigated. Transparent glasses were obtained in a high stoichiometric ratio of nepheline, that is, $75,80,85$, and $90 \%$, whereas the low ones, that is, 25,50 , and $70 \%$, gave devitrified glass samples. In vitro bioactivity testing of the prepared glass batches showed good bioactive behavior of the prepared glass, where $\mathrm{Ca}$ and $\mathrm{P}$ ion release was detected after immersion in Tris-buffered solution for various time intervals.

Despite the advantages of bioactive glass toward tissues, its high modulus of elasticity and brittleness limits its applications; therefore, it has been used in combination with polymethyl-methacrylate (PMMA) to form bioactive bone cement and with metal implants as a coating to form a calcium-deficient carbonated calcium phosphate layer [8].

Bone cements have different applications in dentistry and orthopedic surgery. In dentistry, bone cements are used for sinus floor augmentation, retrograde filling, and in certain cases for anchorage of dental implants. It is widely used in anchoring artificial prostheses to bone. Polymethylmethacrylate (PMMA) is an amorphous self-curing polymer, which is supplied as solid and liquid phases. The solid phase is composed of PMMA, together with benzoyl peroxide as an initiator and barium sulphate as a radiopaque element. The liquid phase is composed of MMA monomer and $N, N^{\prime}$-dimethyl-p-toluidine as an activator. Despite its high mechanical properties, reaching its full strength rapidly, thus providing immediate support after setting, its poor bioactivity has been reported as a cause of debonding at the cement-bone interface $[9,10]$.

This work aims at studying the bioactivity of commercially available PMMA as bone cement through adding the stoichiometric ratio of nepheline-based glasses, that is, 75 , 80,85 , and 90 in mole\%. The effect of 20 and $40 \mathrm{wt} . \%$ glass loading on the in vitro bioactivity of the cements and on the compressive strength was evaluated.

\section{Materials and Methods}

2.1. Preparation of PMMA/Glass Composite Cement Specimens. Preprepared four stoichiometric nepheline/apatite glasses $(75 / 25,80 / 20,85 / 15$, and 90/10 mole\%) were used and mixed with commercially available PMMA (polymethylmethacrylate, $\left(\mathrm{C}_{5} \mathrm{O}_{2} \mathrm{H}_{8}\right)_{n}$, Cemex ${ }^{\circledR}$ Isoplastic, Tecres, Verona, Italy) in two ratios (20 and $40 \mathrm{wt} . \%)$ to form composite samples (Table 1). The chemical composition of the prepared glass batches is listed in Table 2. The glass powder was between 0.212 and $0.150 \mathrm{~mm}$ in grain size. The composite samples were prepared by addition of the glass powder to the monomer
TABle 1: Chemical composition of the tested composite samples.

\begin{tabular}{lccc}
\hline Sample & $\begin{array}{c}\text { PMMA } \\
\text { (weight\%) }\end{array}$ & Weight\% & NeAp \\
\hline \multirow{2}{*}{ NAP75 } & 80 & 20 & NeAp 75 \\
& 60 & 40 & NeAp 75 \\
\hline \multirow{2}{*}{ NAP80 } & 80 & 20 & NeAp 80 \\
& 60 & 40 & NeAp 80 \\
\multirow{2}{*}{ NAP85 } & 80 & 20 & NeAp 85 \\
& 60 & 40 & NeAp 85 \\
\multirow{2}{*}{ NAP90 } & 80 & 20 & NeAp 90 \\
& 60 & 40 & NeAp 90 \\
\hline
\end{tabular}

PMMA: polymethyl-methacrylate.

liquid in a sonicator, and then, the PMMA powder was manually mixed with the glass-filled monomer liquid at a powder : liquid ratio of $3: 1\left(\mathrm{~g} \cdot \mathrm{mL}^{-1}\right)$ to obtain a homogeneous paste. At the dough stage, the mixture was poured into molds for bioactivity and compressive strength. Five samples for each mixture and the control were evaluated for each test.

2.2. In Vitro Bioactivity Assessment. For bioactivity testing, molds to obtain disc specimens with a diameter of $19 \mathrm{~mm}$ and a height of $5 \mathrm{~mm}$ were used. After setting, the specimens were ground on $\mathrm{SiC}$ papers ranging from 600 to 2400 grit and finally polished with 1 and $3 \mu \mathrm{m}$ diamond pastes $[10,11]$. Specimens were immersed in a simulated body fluid (SBF) prepared according to the procedure described by Kokubo [12]. Specimens were individually suspended in $150 \mathrm{ml}$ of freshly prepared SBF for 25 days at physiological conditions of $\mathrm{pH}$ and temperature.

Environmental SEM for high-resolution imaging and elemental analysis system EDX (inspect $S$ with accelerating voltage $30 \mathrm{kV}$, magnification $13 \mathrm{x}$ up to 1000.000 , and resolution $3 \mathrm{~nm}$, FEI Company, Netherlands), using EDX Genesis software (Version 3.6), were used to analyze the specimens' surfaces before and after immersion in SBF.

For identification of the crystalline phases that developed on the specimens' surfaces after immersion in SBF, thin film $\mathrm{X}$-ray diffraction analysis (XRD) (Philips X-ray diffractometer, Amsterdam, Netherlands) was performed. $\mathrm{Cu}-\mathrm{Kx}$ radiation $(\lambda=1.5405)$ was used as the $\mathrm{X}$-ray source.

2.3. Assessment of Ion Release. The initial calcium (Ca) and phosphorus (P) ion concentration release behavior up to 4 hours from the prepared specimens for each mixture was determined. Composite discs were individually suspended in a tightly sealed container filled with $150 \mathrm{ml}$ of freshly prepared Tris-buffer solution at physiological conditions of $\mathrm{pH}$ and temperature $\left(\mathrm{pH} \sim 7.13\right.$ at $\left.37^{\circ} \mathrm{C}\right)$ using a nylon thread to ensure complete solution coverage $[13,14]$. Immersion was done for 10, 125, and 240 minutes. Ten milliliter of the immersion solution was withdrawn for ion concentrations measurement using inductively coupled plasma atomic emission spectroscopy (ICP-OES) (Ultima 2 ICP, Horiba, USA). The concentration of $\mathrm{Al}$ ions released in SBF after specimen immersion for 25 days was also evaluated. 
TABLe 2: Chemical composition of the glass batches.

\begin{tabular}{lcccccccrr}
\hline \multirow{2}{*}{ Sample number } & \multicolumn{3}{c}{ Molar ratio } & \multicolumn{9}{c}{ Composition/mass- $\%$} & $\mathrm{Na}_{2} \mathrm{O}$ & $\mathrm{CaF}_{2}$ & $\mathrm{P}_{2} \mathrm{O}_{5}$ & Product \\
& $\mathrm{Ne}$ & $\mathrm{Ap}$ & $\mathrm{SiO}_{2}$ & $\mathrm{Al}_{2} \mathrm{O}_{3}$ & $\mathrm{CaO}$ & 12.83 & Transparent glass \\
\hline NeAp 75 & 75 & 25 & 31.72 & 26.92 & 12.83 & 16.36 & 1.35 & 10.83 & Transparent glass \\
NeAp 80 & 80 & 20 & 33.83 & 28.71 & 10.26 & 17.46 & 1.08 & 9.06 & Transparent glass \\
NeAp 85 & 85 & 15 & 35.95 & 30.51 & 7.70 & 18.55 & 0.81 & 6.79 & Transparent glass \\
NeAp 90 & 90 & 10 & 38.06 & 32.30 & 5.13 & 19.64 & 0.54 & 4.53
\end{tabular}

Ne: nepheline $\left(\mathrm{NaAlSiO}_{4}\right)$; Ap: fluorapatite $\left(\mathrm{Ca}_{5}\left(\mathrm{PO}_{4}\right)_{3} \mathrm{~F}\right)$.

The $\mathrm{pH}$ changes of Tris-buffer solution after specimens' immersion were monitored every 10 minutes up to 195 minutes using a calibrated digital $\mathrm{pH}$ meter (Jenway 3510 bench $\mathrm{pH}$ meter, UK).

2.4. Compressive Strength Testing. The compressive strength testing was done according to the standard specification for acrylic bone cement specified in the ASTM F-451-99 standard [15]. Five cylindrical specimens with a diameter of $12 \mathrm{~mm}$ and a height of $6 \mathrm{~mm}$ for each composition were prepared and then placed in a desiccator before testing. Testing was done using a computer-controlled universal testing machine (LRXplus, Lloyd Instruments Universal Test Machine, Fareham, UK) by applying a compressive load at a crosshead speed of $0.5 \mathrm{~mm} / \mathrm{min}$. Data were recorded using Nexygen-MT software (Version 4.2). The average and standard deviation were calculated.

2.5. Statistical Analysis. The mean and standard deviation values were calculated for each group in each test. Data were explored for normality using Kolmogorov-Smirnov and Shapiro-Wilk tests. Repeated measure ANOVA was used to compare between dependent samples for more than two groups. One-way ANOVA was used to compare between independent samples for more than two groups. The significance level was set at $P \leq 0.05$. Statistical analysis was performed with IBM ${ }^{\circledR}$ SPSS $^{\circledR}$ Statistics Version 20 in Windows.

\section{Results and Discussion}

A fast and simple method for determination of the in vitro bioactive behavior of the material is performed through studying the $\mathrm{pH}$ changes and ion release in the solution. Additionally, the ability of a material to form a calcium phosphate layer in vitro after partial leaching and dissolution is often taken as a measure of its bioactivity in vivo [2].

Figures 1 and 2 show SEM images and the corresponding EDX spectra of the control and the glass-filled specimens after immersion in SBF for 25 days. No obvious changes were evident on the surface of the control specimens; it shows only the polymer beads were surrounded by in situ PMMA. Such finding is confirmed by the EDX spectrum, which shows the absence of $\mathrm{Ca}$ and $\mathrm{P}$ precipitates. Barium in the form of barium sulphate $(9.00 \% \mathrm{w} / \mathrm{w})$ added by the bone cement manufacturer as radio-opacifier (i.e., rendering the bone cement visible with X-ray imaging of the patient after treatment) appeared on the surface of the control and the tested specimens. On the contrary, SEM images revealed irregular precipitates on the surfaces of the glass-filled specimens of all compositions. The morphology and thickness of the formed layer varied with the glass composition and the weight percentage predominantly on $40 \%$ glass concentration. EDX spectrum shows the presence of $\mathrm{Ca}-$ and P-rich agglomerates on their surfaces. The $\mathrm{Ca} / \mathrm{P}$ atomic ratio of the layers formed on the tested specimens was calculated from the EDX results and is listed in Table 3. These values are close to the $\mathrm{Ca} / \mathrm{P}$ ratio of hydroxyapatite (1.67), fluorapatite (1.67), tetracalcium phosphate (2.00), and octacalcium phosphate (1.33) [16].

The thin film XRD patterns of the cement composite surfaces after immersion in SBF for 25 days are shown in Figures 3 and 4 . The results confirmed the formation of apatite phase $\left[\mathrm{Ca}_{5}\left(\mathrm{PO}_{4}\right)_{3}(\mathrm{OH})\right]$, whereas patterns of barite $\left(\mathrm{BaSO}_{4}\right)$ and low quartz $\left(\mathrm{SiO}_{2}\right)$ were also detected on the surface of the tested specimens.

The process of formation of the calcium phosphate layer on a substrate surface starts, provided that the critical supersaturation of the surrounding solution is reached. Seeded crystal growth on a substrate containing calcium phosphate takes place at considerably lower supersaturations of aqueous solutions. Epitaxy is one of the reasons why certain materials can function as seeding nuclei for other materials. The growth of one crystal on another takes place when atomic dimensions of one or more commonly occurring faces of each are similar. Therefore, a number of phases may form in the order of decreasing solubility: amorphous calcium phosphate (ACP), dicalcium phosphate dihydrate (DCPD) $\mathrm{CaHPO}_{4} \cdot 2 \mathrm{H}_{2} \mathrm{O}$, anhydrous calcium phosphate (DCPA) $\mathrm{CaHPO}_{4}$, octacalcium phosphate $\mathrm{Ca}_{8} \mathrm{H}_{2}\left(\mathrm{PO}_{4}\right)$ $6.5 \mathrm{H}_{2} \mathrm{O}(\mathrm{OCP}), \beta$-tricalcium phosphate ( $\beta$-TCP), $\mathrm{Ca}_{3}\left(\mathrm{PO}_{4}\right)_{2}$, and hydroxyapatite $\left(\mathrm{Ca}_{10}\left(\mathrm{PO}_{4}\right)_{6}(\mathrm{OH})_{2}\right.$; HAP) [16]. Such a finding explains the formation of the calcium phosphate phase $\left[\mathrm{Ca}_{5}\left(\mathrm{PO}_{4}\right)_{3}(\mathrm{OH})\right]$ precipitated on the specimen's surfaces with different glass compositions and loading, which are revealed in this study.

The effect of incorporation of $\mathrm{Al}_{2} \mathrm{O}_{3}$ in glass composition and its effect on ion release and bioactivity were investigated in previous studies. The results of the present investigation is in agreement with a study done by El-Kheshen [4] who reported that the bioactivity increased by gradual addition of $\mathrm{Al}_{2} \mathrm{O}_{3}$, which was indicated by the acceleration in the formation of the hydroxyl apatite layer on the glass surface after immersion in simulated body fluid. However, in a study done by Melchers et al. [5], it was postulated that the incorporation of $\mathrm{Al}_{2} \mathrm{O}_{3}$ did not significantly affect the bioactivity and may slightly improve it; however, increasing its concentration adversely affected the bioactivity. They 


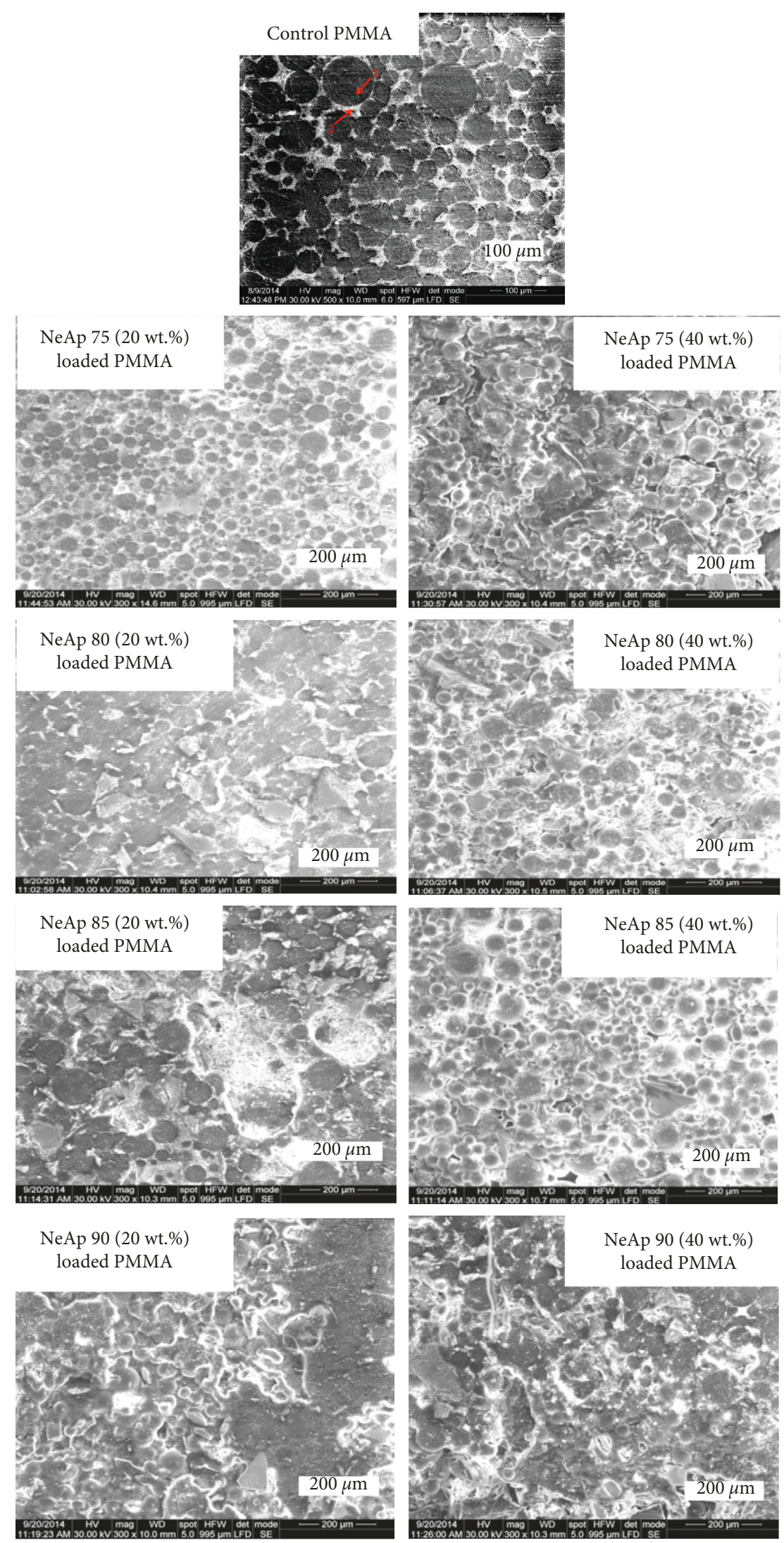

FIGURE 1: SEM images of the control and the glass-filled specimens after immersion in SBF for 25 days. 

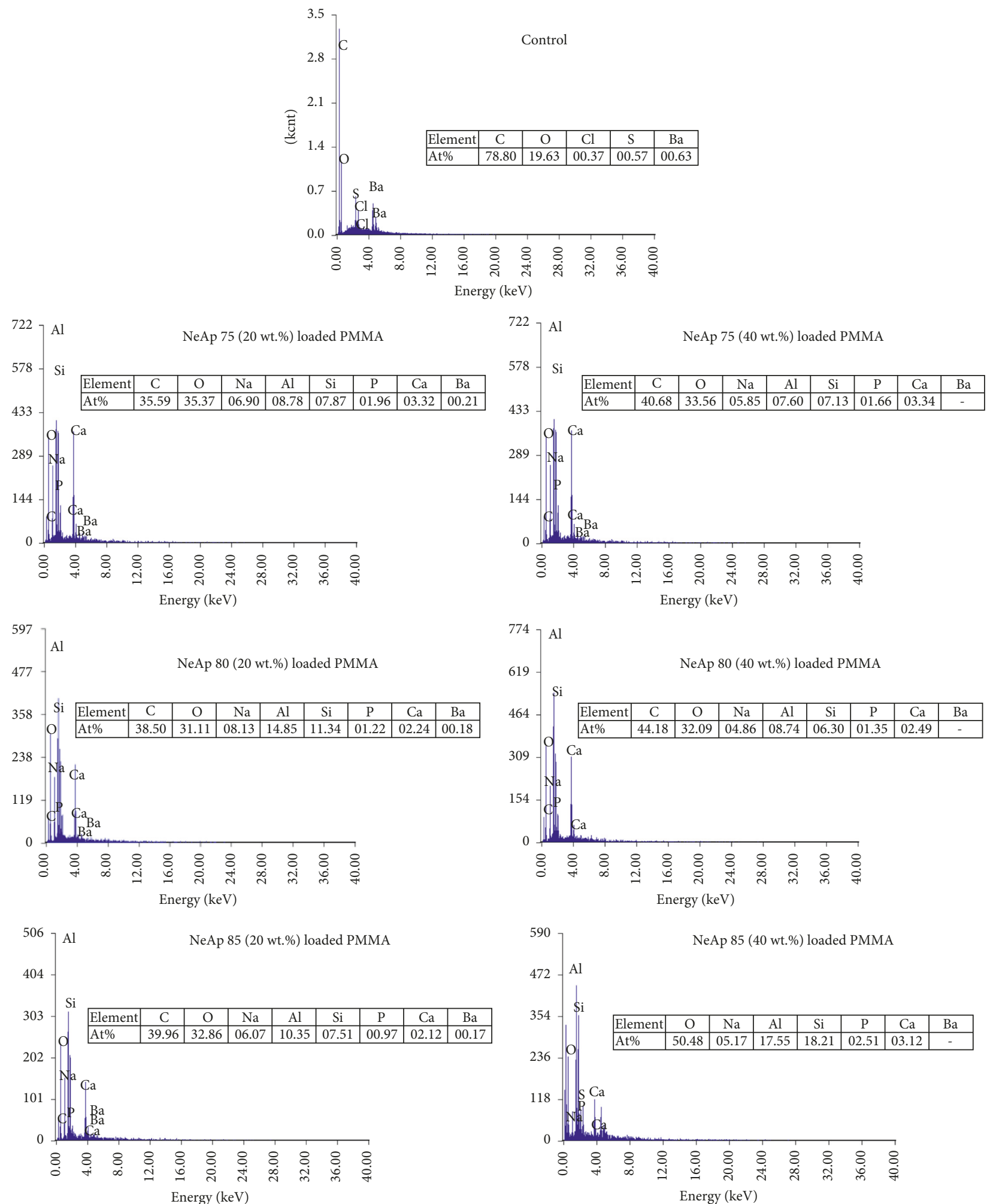

Figure 2: Continued. 

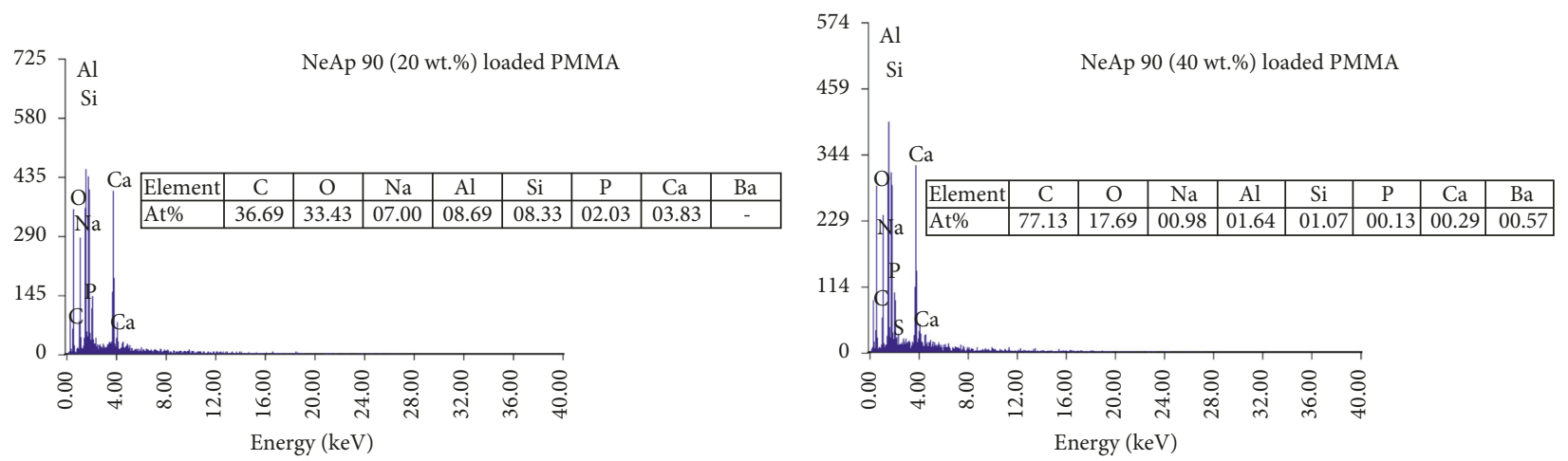

FIGURE 2: EDX spectra of the control and the glass-filled specimens after immersion in SBF for 25 days.

TABLE 3: Calcium/phosphate molar ratios as revealed by EDX analysis of the tested specimens surfaces.

\begin{tabular}{lcccccccc}
\hline Specimens & $\begin{array}{c}\text { NeAp 75 } \\
(20 \%)\end{array}$ & $\begin{array}{c}\text { NeAp 75 } \\
(40 \%)\end{array}$ & $\begin{array}{c}\text { NeAp } 80 \\
(20 \%)\end{array}$ & $\begin{array}{c}\text { NeAp } 80 \\
(40 \%)\end{array}$ & $\begin{array}{c}\text { NeAp } 85 \\
(20 \%)\end{array}$ & $\begin{array}{c}\text { NeAp 85 } \\
(40 \%)\end{array}$ & $\begin{array}{c}\text { NeAp 90 } \\
(20 \%)\end{array}$ & $\begin{array}{c}\text { NeAp 90 } \\
(40 \%)\end{array}$ \\
\hline $\mathrm{Ca} / \mathrm{P}$ & 1.69 & 2.12 & 1.83 & 1.84 & 2.2 & 1.2 & 1.8 & 1.6 \\
\hline
\end{tabular}

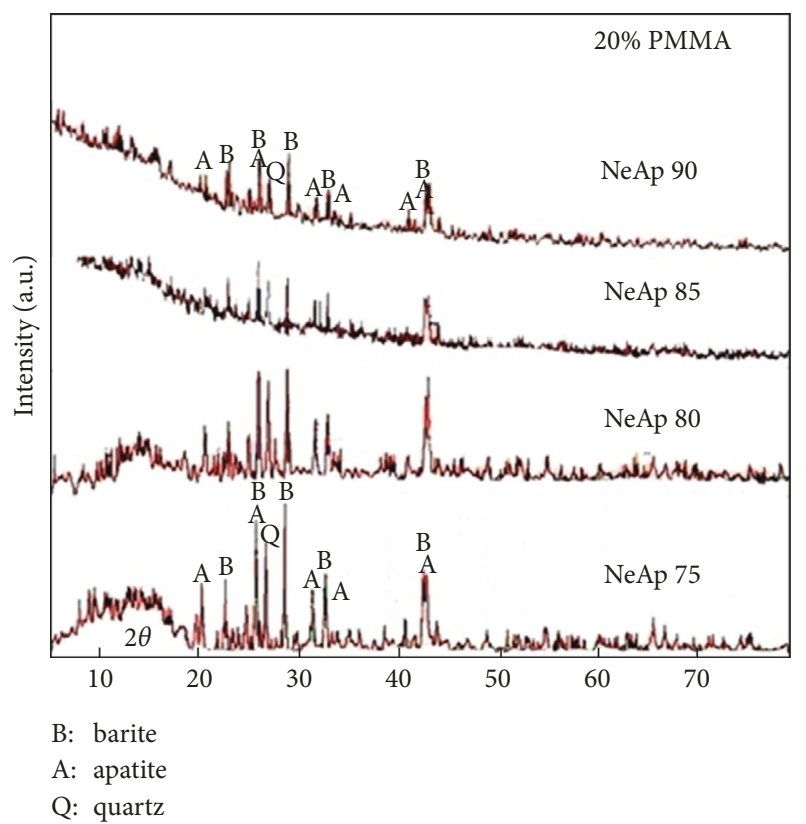

FIGURE 3: Thin film X-ray diffraction patterns of the specimens' surface with $20 \%$ glass loading.

postulated that at higher $\mathrm{Al}_{2} \mathrm{O}_{3}$ concentrations the required charge compensation produced through the interaction of $\mathrm{Al}^{3+}$ and $\mathrm{PO}_{4}{ }^{3-}$ and trapping of $\mathrm{Ca}^{2+}$ may obstruct the release of $\mathrm{Ca}, \mathrm{P}$, and $\mathrm{Si}$ ions required for the formation of hydroxycarbonate apatite. Another study [17] suggested that the presence of both mullite $\left(\mathrm{Al}_{6} \mathrm{Si}_{5} \mathrm{O}_{13}\right)$ structural units and fluorapatite structural units in glass might act as bonding agents between the bone mineral and the glass.

The early release of $\mathrm{Ca}$ and $\mathrm{P}$ is confirmed by the results of ICP analysis, and the results are shown in Figures 5 and 6. For all compositions and concentrations, the high statistically significant mean value of cation concentration

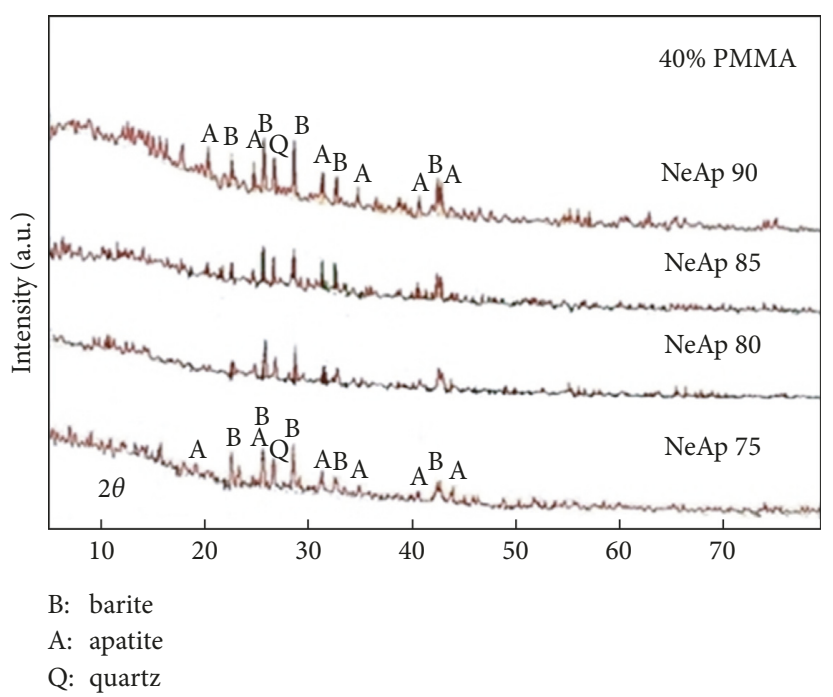

Figure 4: Thin film X-ray diffraction patterns of the specimens' surface with $40 \%$ glass loading.

was found after $240 \mathrm{~min}$ of immersion $(p \leq 0.001)$, indicating a gradual increase in $\mathrm{Ca}$ ion release with time. Specimens loaded with NeAp 75 glass showed the highest mean value of calcium ion release probably due to the higher fluorapatite content and the least $\mathrm{Al}_{2} \mathrm{O}_{3}$ percent. On the contrary, the lowest statistically significant mean value of $\mathrm{P}$ ion concentration was found after $240 \mathrm{mins}$, except that of NeAp 75 (20\%) where the highest significant mean value of $\mathrm{P}$ ion concentration was found after $240 \mathrm{~min}$ of immersion $(p \leq 0.001)$. Such finding is an indication of early release of $\mathrm{P}$ ion with a gradual decrease with time due to the consumption of $\mathrm{P}$ in apatite layer formation. Regarding NeAp 75 (20\%), results indicate that the rapid release starts after 125 min of immersion.

Due to concerns regarding the biocompatibility of $\mathrm{Al}$, the concentration of $\mathrm{Al}$ ion in SBF after specimen's 


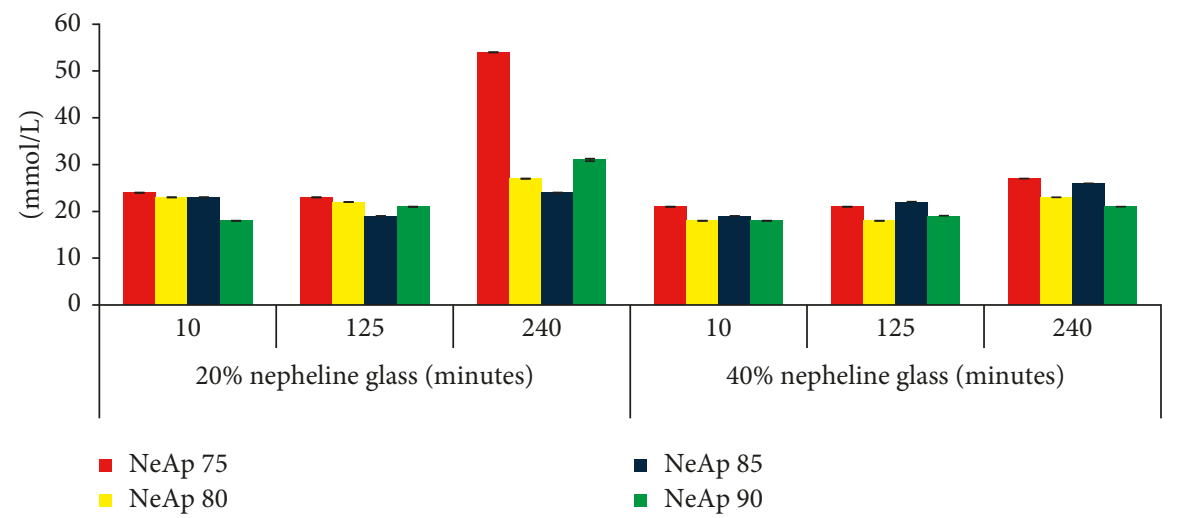

FIgURE 5: Change in Ca concentrations $(\mathrm{mmol} / \mathrm{L})$ in Tris-buffer solution as a function of soaking time.

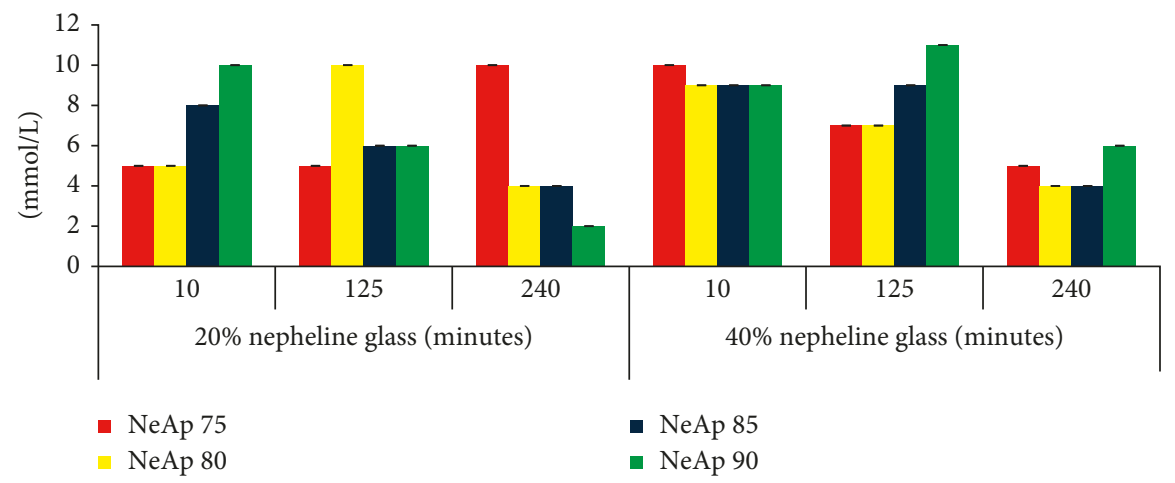

Figure 6: Change in $\mathrm{P}$ concentrations $(\mathrm{mmol} / \mathrm{L})$ in Tris-buffer solution as a function of soaking time.

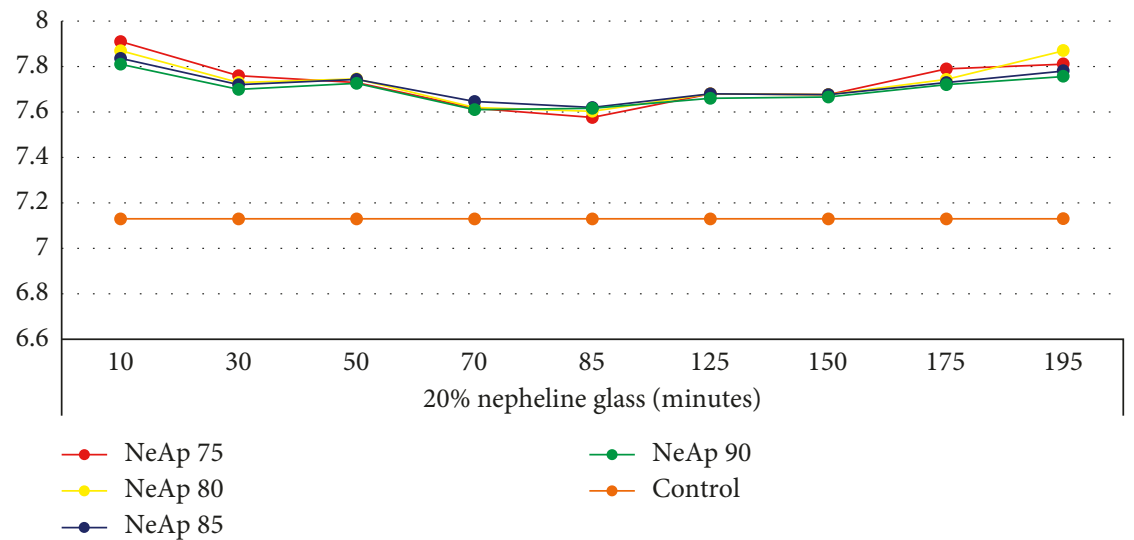

Figure 7: pH changes of Tris-buffer solution along different time periods for each $20 \%$ NeAp glass type.

immersion for 25 days was evaluated. Results revealed that the concentration of $\mathrm{Al}$ ions was less than $0.01 \mathrm{mg} / \mathrm{l}$ for all the tested materials. Meyera et al. [18], evaluated biologically glass ionomer bone cement (GIC) by osteoblast cell culture methods. GIC is a calcium aluminosilicate glass containing fluoride, to be mixed with a homopolymer or copolymer of alkenoic acids. The average composition (wt. \%) of GIC bone cement is $\mathrm{SiO}_{2}(35 \%), \mathrm{Al}_{2} \mathrm{O}_{3}(30 \%), \mathrm{CaO}$ (15\%), fluorine (10\%), $\mathrm{Na}_{2} \mathrm{O}(3 \%)$, and $\mathrm{P}_{2} \mathrm{O}_{5}(7 \%)$. It was reported that although accumulation of aluminum was noticed in osteoblasts cultivated in vitro in the presence of glass ionomer bone cement, the cells revealed normal physiological activity with no signs of toxicity as determined by light and scanning electron microscopy. However, further investigations regarding the biocompatibility and cytotoxicity for the prepared PMMA/nepheline-fluorapatite glass composites are required.

Results of the changes in $\mathrm{pH}$ measured in this study showed a rapid increase in $\mathrm{pH}$ after 10 minutes and during the testing period (Figures 7 and 8). The rapid increase in $\mathrm{pH}$ 


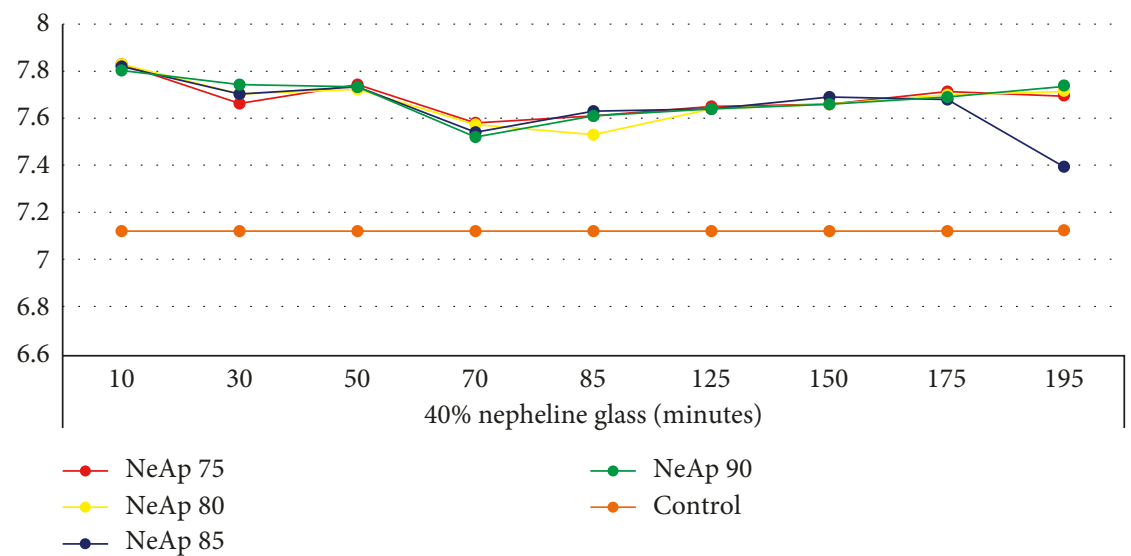

Figure 8: pH changes of Tris-buffer solution along different time periods for each $40 \%$ NeAp glass type.

TABLE 4: The mean and standard deviation (SD) values of compressive strength $(\mathrm{MPa})$ in each group.

\begin{tabular}{lccc}
\hline Variables & $\begin{array}{c}20 \% \text { glass } \\
(\text { mean } \pm S D)\end{array}$ & $\begin{array}{c}40 \% \text { glass } \\
(\text { mean } \pm S D)\end{array}$ & $p$ value \\
\hline Control & $97.30 \pm 3.90^{\mathrm{aA}}$ & $97.30 \pm 3.90^{\mathrm{aA}}$ & $1, \mathrm{~ns}$ \\
NeAp 75 & $87.14 \pm 6.65^{\mathrm{aA}}$ & $70.83 \pm 3.31^{\mathrm{acA}}$ & $0.309, \mathrm{~ns}$ \\
NeAp 80 & $91.13 \pm 6.26^{\mathrm{aB}}$ & $76.34 \pm 5.57^{\mathrm{acA}}$ & $0.038^{*}$ \\
NeAp 85 & $92.98 \pm 5.93^{\mathrm{aA}}$ & $70.36 \pm 6.47^{\mathrm{bcB}}$ & $0.011^{*}$ \\
NeAp 90 & $96.90 \pm 2.94^{\mathrm{aB}}$ & $85.17 \pm 6.82^{\mathrm{aA}}$ & $0.019^{*}$ \\
$p$ value & $\leq 0.001^{*}$ & $0.085, \mathrm{~ns}$ & \\
\hline
\end{tabular}

Means with different lower case letters in the same column indicate statistically significant difference, while means with different upper case letters in the same row indicate statistically significant difference; ${ }^{*}$ significant $(p<0.05)$; ns: nonsignificant $(p>0.05)$.

is the result of rapid release of alkali ions into the solution where the particles started to leach and dissolve immediately when in contact with Tris-buffer solution [19]. Such finding is in good agreement with observations of immersion of glass 45S5 particles in Tris-buffered solutions by Cerruti et al. and Greenspan et al. $[19,20]$ in which a rapid increase in $\mathrm{pH}$ took place in the solution during the first $2-6 \mathrm{~h}$. The highest mean $\mathrm{pH}$ value was found after $10 \mathrm{~min}$ of immersion in all groups. 20\% NeAp 75 specimens showed the highest mean $\mathrm{pH}$ value $(\mathrm{pH}=7.910)$ after 10 min of immersion, which falls within the physiological limit of human tissues.

Compressive strength testing was done to evaluate the proper glass weight percent that is able to bioactivate the PMMA polymer without adversely affecting the compressive strength of bone cement. Table 4 shows the mean and standard deviation (SD) values of compressive strength in each group. A statistically significant decrease in compressive strength was observed as the filler content was increased in all groups except for NeAp 75 where no statistical significant difference was observed $(p>0.05)$. No statistically significant difference was observed between all groups with different glass percentages and the control group except for NeAp 85 $(40 \%)$ where a statistical significant decrease in compressive strength $(70.36 \mathrm{MPa})$ was noticed. This may be attributed to the fact that the glass particles act as stress concentration areas. According to the ASTM F-451, a minimum value of $70 \mathrm{MPa}$ is essential for bone cements [15]; thus, the tested groups meet this mechanical requirement. The decrease in compressive strength of PMMA bone cement with increasing the filler loading is in agreement with the results obtained by Rentería-Zamarrón et al. [11], where the compressive strength of the cement was decreased with increasing of wollastonite $\left(\mathrm{CaSiO}_{3}\right)$ content.

\section{Conclusions}

Bioactive PMMA bone cements could be obtained by adding 20 and $40 \mathrm{wt} . \%$ in all the composite samples containing all glass ratios of stoichiometric nepheline, that is, $75,80,85$, and $90 \%$. On the contrary, SEM/EDX spectrum and thin film XRD confirmed the formation of the apatite phase on the surfaces of all the composite specimens. The increase in the glass ratio (i.e., $40 \mathrm{wt} . \%$ ) decreases the compressive strength values, but all meet that specified by the ASTM F-451.

\section{Data Availability}

The data used to support the findings of this study are available from the corresponding author upon request.

\section{Conflicts of Interest}

The authors declare that they have no conflicts of interest.

\section{References}

[1] C. Vichery and J.-M. Nedelec, "Bioactive glass nanoparticles: from synthesis to materials design for biomedical applications," Materials, vol. 9, no. 4, pp. 288-296, 2016.

[2] D. Zhang, M. Hupa, and L. Hupa, "In situ pH within particle beds of bioactive glasses," Acta Biomaterialia, vol. 4, pp. 1498-1505, 2008.

[3] P. Lopes, M. Corbellini, B. L. Ferreira et al., "New PMMA-coEHA glass-filled composites for biomedical applications: mechanical properties and bioactivity," Acta Biomaterialia, vol. 5, no. 1, pp. 356-362, 2009. 
[4] A. A. El-Kheshen, F. A. Khaliafa, E. A. Saad, and R. L. Elwan, "Effect of $\mathrm{Al}_{2} \mathrm{O}_{3}$ addition on bioactivity, thermal and mechanical properties of some bioactive glasses," Ceramics International, vol. 34, no. 7, pp. 1667-1673, 2008.

[5] S. Melchers, T. Uesbeck, O. Winter, H. Eckert, and D. Eder, "Effect of aluminium ion incorporation on the bioactivity and structure in mesoporous bioactive glasses," Chemistry of Materials, vol. 28, no. 10, pp. 3254-3264, 2016.

[6] N. Y. Mikhailenko, E. E. Stroganova, and N. V. Buchilin, "Solubility of calcium phosphate glasses and glass ceramic materials in water and physiological media," Glass and Ceramics, vol. 70, no. 3-4, pp. 3-4, 2013.

[7] E. M. A. Hamzawy, O. A. Alharbi, and D. Y. Zaki, "Characterization and bioactivity in high cristobalite-nepheline-apatite glass and glass ceramics," Interceram, vol. 65, pp. 32-36, 2016.

[8] J. Slane, J. Vivanco, J. Meyer, H.-L. Ploeg, and M. Squire, "Modification of acrylic bone cement with mesoporous silica nanoparticles: effects on mechanical, fatigue and absorption properties," Journal of the Mechanical Behavior of Biomedical Materials, vol. 29, pp. 451-461, 2014.

[9] R. Vaishya, M. Chauhan, and A. Vaish, "Bone cement," Journal of Clinical Orthopaedics and Trauma, vol. 4, no. 4, pp. 157-163, 2013.

[10] A. L. Fernandes da Silva, A. M. Borba, N. R. Simão, F. L. M. Pedro, A. H. Borges, and M. Miloro, "Customized polymethyl methacrylate implants for their construction of craniofacial osseous defects," Case Reports in Surgery, vol. 2014, Article ID 358569, 8 pages, 2014.

[11] D. Rentería-Zamarrón, D. A. Cortés-Hernández, L. BretadoAragón, and W. Ortega-Lara, "Mechanical properties and apatite-forming ability of PMMA bone cements," Materials and Design, vol. 30, no. 8, pp. 3318-3324, 2009.

[12] T. Kokubo and H. Takadama, "How useful is SBF in predicting in vivo bone bioactivity?" Biomaterials, vol. 27, no. 15, pp. 2907-2915, 2006.

[13] M. Marques, "Simulated biological fluids with possible application in dissolution testing," Dissolution Technologies, vol. 18 , no. 3 , pp. 15-28, 2011.

[14] L. Chen, D. Zhai, Z. Huan et al., "Silicate bioceramic/PMMA composite bone cement with distinctive physicochemical and bioactive properties," RSC Advances, vol. 5, no. 47, pp. 37314-37322, 2015.

[15] ASTM F451-08 Standard Specification for Acrylic Bone Cement, 2003, http://www.astm.org/Standards/F451.htm.

[16] Z. Amjad, Calcium Phosphates in Biological and Industrial Systems, p. 515, Kluwer Academic Publishers, New York, NY, USA, 1998.

[17] D. Wood and R. Hill, "Glass ceramic approach to controlling the properties of a glass-ionomer bone cement," Biomaterials, vol. 12, no. 2, pp. 164-170, 1991.

[18] U. Meyera, D. H. Szulczewskia, R. H. Barckhaus, M. Atkinson, and D. B. Jonesa, "Biological evaluation of an ionomeric bone cement by osteoblast cell culture methods," Biomaterials, vol. 14, no. 12, pp. 917-924, 1993.

[19] M. G. Cerruti, D. Greenspan, and K. Powers, "An analytical model for the dissolution of different particle size samples of bioglass in Tris buffered solution," Biomaterials, vol. 26, no. 24, pp. 4903-4911, 2005.

[20] D. C. Greenspan, I. P. Zhong, and G. P. La Torre, "Effect of surface area to volume ratio on in vitro surface reactions of bioactive glass particulates," Bioceramics, vol. 7, pp. 55-60, 1994. 


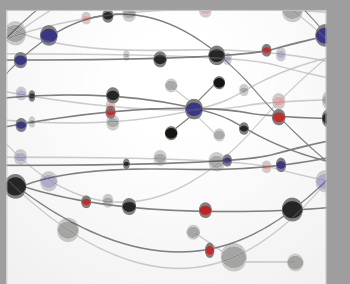

The Scientific World Journal
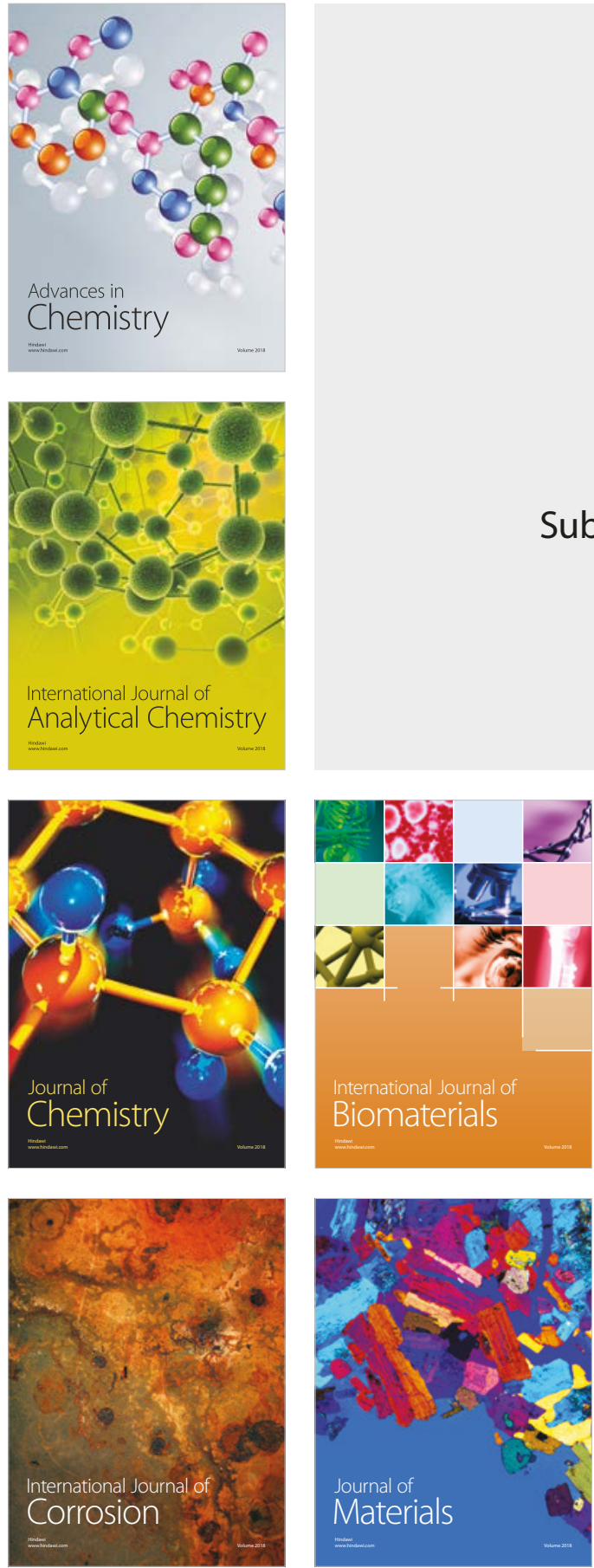

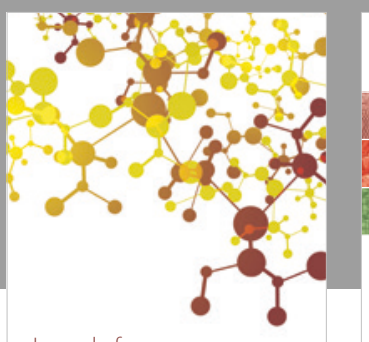

Journal of

Applied Chemistry
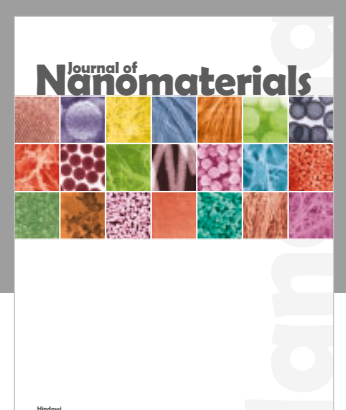

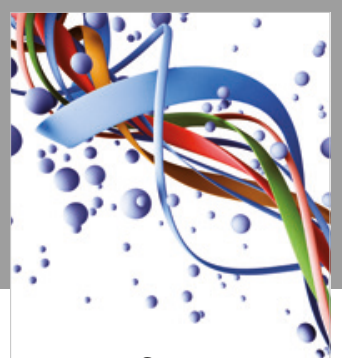

Scientifica

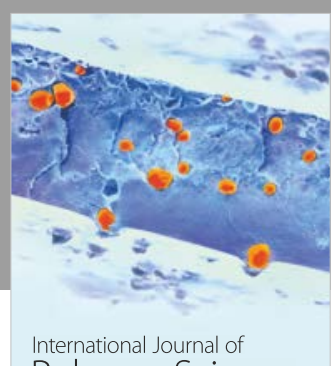

Polymer Science

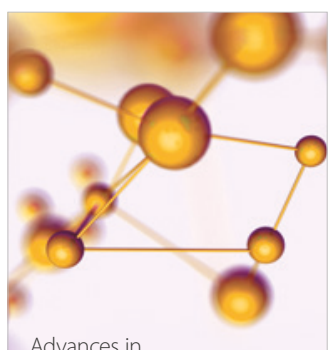

Physical Chemistry
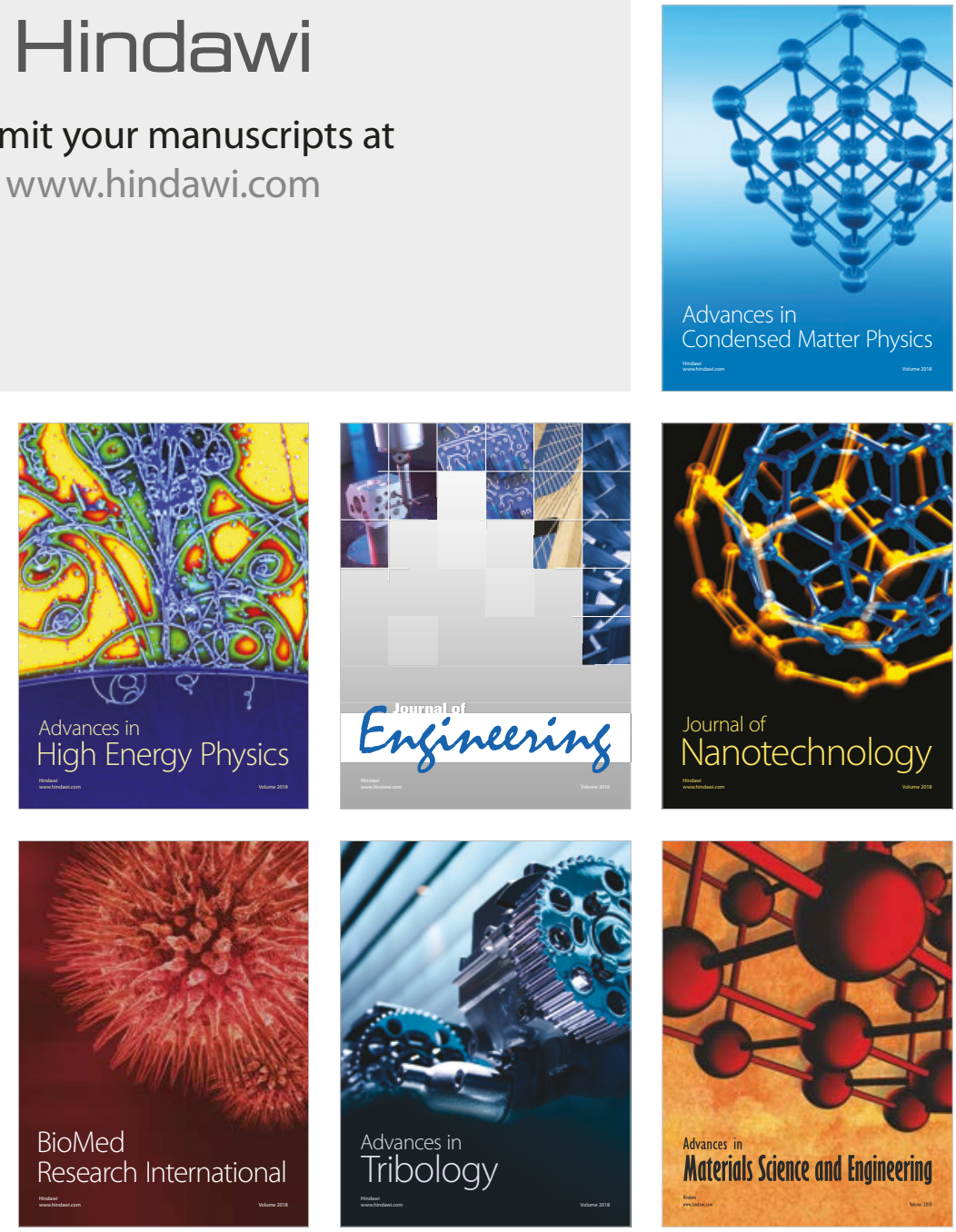